\title{
Meat productivity and quality of goose meat when using nanostructural zeolite in feeding
}

Yulia Larina ${ }^{1,2^{*}}$, Vladimir Ezhkov ${ }^{2,3}$, Ramil Fayzrakhmanov ${ }^{4}$ and Asia Ezhkova ${ }^{2,4}$

${ }^{1}$ Federal Center for Toxicological, Radiation and Biological Safety, Kazan 420075, Russia

${ }^{2}$ Tatar Scientific Research Institute of Agrochemistry and Soil Science Federal Research Center Kazan Scientific Center of the Russian Academy of Sciences, Kazan 420059, Russia

${ }^{3}$ Kazan National Research University of Technology, Kazan 420011, Russia

${ }^{4}$ Kazan State Academy of Veterinary Medicine named after N.E. Bauman, Kazan 420074, Russia

\begin{abstract}
The article presents comparative studies of the meat productivity of geese of the Lindovskaya breed when zeolite and nanostructured zeolite feed additives are introduced into their diets. It was shown that the use of zeolite contributed to an increase in the live weight of geese by $4.0 \%$, the use of differen doses of nanostructured zeolite led to an increase by $6.2-10.2 \%(\mathrm{P} \leq 0.05)$, in comparison with control analogues. When using zeolite in meat, the content of zinc and copper salts decreased by 28.0 and $13.1 \%$. The introduction of nanostructured zeolite into the diet led to a decrease in zinc content by $27.5-31.3 \%$ and that of copper by $27.1-48.6 \%$ compared with the control. The meat of birds of all groups corresponded to hygienic quality requirements for the content of chemical elements.
\end{abstract}

\section{Introduction}

Increasing poultry production, improving quality and reducing its cost remains relevant at the present stage, as it allows you to solve issues of food safety.

In recent years, increased demands have been made as for the quality of livestock products. The consume market dictates the need for livestock production withou the use of chemical and synthetic drugs in the cultivation of animals and birds. In this case, natural agrominerals bentonites, zeolites, vermiculites, etc., whose deposits in a diverse composition and quantity are present in the Russian Federation and the Republic of Tatarstan become unique substitutes for biogenic components in living organisms $[1,2]$.

Zeolites are widely known in the scientific literature and are used in the feeding of farm animals; clinoptilolite is the most popular zeolite to be used as a zootechnical and biomedical ingredient [3]

Zeolites are crystalline hydrated aluminosilicates with specific physical and chemical properties that provide sorption and desorption of water, adsorption of molecules, they act as molecular sieves, and replace cations without structural changes in the mineral. Over the past 50 years, commercial production of natural zeolites has accelerated.

The Commission of the International Association of Zeolites has registered more than two hundred product names based on raw materials from more than 40 natural zeolite deposits [4].

Interest in the use of zeolite is increasing due to their beneficial properties, lack of toxicity, positive results in

\footnotetext{
*Corresponding author: larinavnivi@ mail.ru
}

reducing the incidence of animal diseases, increasing the productivity and safety of animal products $[5,6]$.

Zeolites are completely harmless, do not contain toxic substances, and cannot harbour microorganisms [7]. The rate of feed passage through the gastrointestinal tract of animals under the influence of zeolites slows down, which contributes to a more complete digestion and use of nutrients.

Zeolite acts as an ion exchanger and regulates the ratio of calcium and sodium in the body, improves the supply of soft tissues with iron. The authors believe that an increase in feed digestibility under the influence of zeolite is associated with the introduction of an easily digestible mobile form of potassium and calcium, some trace elements, due to the buffering effect of tuff, which stabilizes the acidity of gastric juice, as well as the absorption and removal of toxic digestion products and food toxins from the body [8-10]. S. Wang et al. [11] obtained similar results indicating an increase in mineral metabolism in birds under the influence of zeolite, accompanied by an increased content of macro- and microelements in tissues and organs.

The active surface of natural zeolites exerts its influence on the enzymatic activity of digestive enzymes, while molecular sieve properties and sorption activity contribute to the binding of intestinal and blood toxins by zeolites [12-15].

Analysis of modern literature on the use of zeolites in biotechnology and medicine showed that zeolites are promising for protecting the environment, detoxifying living organisms, improving the digestive and immune systems of farm animals, separating different biomolecules and cells, constructing biosensors and 
detecting biomarkers of various diseases controlled delivery of drugs and genes, purification from radicals [16].

In the scientific literature of recent years, studies have been published on the use of zeolites containing nanosized particles that exhibit higher biological effects in living organisms in comparison with macro analogs [17]. Methods of manufacturing nanostructured zeolites [18] are presented; the conditions for steric stabilization of zeolite nanoparticles [19] are shown.

In this context, the aim of the work was to study the effect of nanostructured zeolite in the form of a feed additive on the meat productivity and quality of goose meat.

\section{Material and research methods}

The objects of research were nanostructured zeolite geese of the Lindovskaya breed, their meat.

Nanostructured zeolite with particle sizes of $50.0-160.0 \mathrm{~nm}$ was produced by ultrasonic dispersion of the thermo-mechanically activated zeolite from the Tatar-Shatrashansky deposit. An UP-400S ultrasonic homogenizer (Hielscher, Germany) was used to fabricate a nanostructured zeolite. The power of the dispersing device was $70 \%$ at a frequency of $24 \mathrm{kHz}$. To determine the particle size, a Brookhaven 90Plus / MAS nanoparticle analyzer (USA) and a MultiMode V scanning probe microscope from Veeco (USA) were used.

Scientific and industrial experience was carried out on the basis of "KFH A.R. Akhmetov" farm in Vysokogorsky district of the Republic of Tatarstan (RT). Five groups of geese were formed with 75 animals each at the age of 30 days (Table 1)

Table 1. Scheme of scientific and production experiments.

\begin{tabular}{|c|c|}
\hline Groups & Diet features \\
\hline $\begin{array}{c}\text { I } \\
\text { control group }\end{array}$ & $\begin{array}{l}\text { The main diet is a complete feed } \\
\text { "GKZ complete feed for geese" } \\
\text { (MD) }\end{array}$ \\
\hline $\begin{array}{c}\text { II } \\
\text { experimental } \\
\text { group }\end{array}$ & $\begin{array}{c}\mathrm{MD}+1.5 \% \text { zeolite to dry matter } \\
\text { feed }\end{array}$ \\
\hline $\begin{array}{l}\text { III } \\
\text { experimental } \\
\text { group }\end{array}$ & $\begin{array}{l}\mathrm{MD}+1.5 \% \text { nanostructured zeolite } \\
\text { to dry matter feed }\end{array}$ \\
\hline $\begin{array}{l}\text { IV } \\
\text { experimental } \\
\text { group }\end{array}$ & $\begin{array}{c}\mathrm{MD}+1.0 \% \text { nanostructured zeolite } \\
\text { to dry matter feed }\end{array}$ \\
\hline $\begin{array}{l}\mathrm{V} \\
\text { experimental } \\
\text { group }\end{array}$ & $\begin{array}{l}\mathrm{MD}+0.5 \% \text { nanostructured zeolite } \\
\text { to dry matter feed }\end{array}$ \\
\hline
\end{tabular}

Watering geese was conducted under running wate centrally using a drinking system. The geese were kept floor-standing on sawdust in a brick building with a concrete floor and an outdoor way. The ventilation in the building was natural and fresh.

In the dynamics of the experimental period at the age of geese 30,60, 90 and 120 days, the increase in live weight was determined by individual weighing of birds with "Mercury 315" electronic balance, class IV accuracy.

The content of copper, zinc, nickel, lead and cadmium compounds in meat was determined according to GOST 30538-97 on an Agilent 4210 atomic emission spectrometer with microwave plasma.

In meat, the moisture content was determined according to GOST R 51479-99 "Meat and meat products. The method of determining the mass fraction of moisture", the amount of fat - by the Soxhlet method, the amount of protein - according to Kjeldahl, the content of mineral substances - by burning in a muffle furnace. Energy value was determined by calculation.

\section{Research results}

When studying the structure of thermo-mechanically activated zeolite, it was found that it is represented by conglomerates of particles of two sizes: $350-400$ and $400-1600 \mathrm{~nm}$. After ultrasonic dispersion of the zeolite, a change in its structure was noted - the destruction of conglomerates into smaller particles. It was found that morphologically these particles had polygonal shapes of three sizes: 5-20 nm, their share was 5\%,50-95 nm $75 \%, 100-160 \mathrm{~nm}-20 \%$.

A detailed study found that the particles of the third group are conglomerates consisting of the above small particles. Modification of the zeolite to the nanostructured state ensured a change in shape and a decrease in the size of its particles, which undoubtedly caused a change in its properties. The authors showed that in animals, when using drugs containing active nanoparticles, there is an increase or even a change in the known biological effects [20].

In the study of indicators of meat productivity, an increase in the live weight of birds was established (Table 2).

Table 2. Live weight, absolute and average daily gain of geese, g.

\begin{tabular}{|c|c|c|c|c|c|}
\hline \multirow{2}{*}{ Age, weeks } & \multicolumn{5}{|c|}{ Groups $(n=75)$} \\
\hline & $\mathrm{I}$ & II & III & IV & $\mathrm{V}$ \\
\hline 4 & $\begin{array}{l}1790.0 \\
\pm 11.2 \\
\end{array}$ & $\begin{array}{c}1780.0 \\
\pm 14.2\end{array}$ & $\begin{array}{c}1795.0 \\
\pm 16.8\end{array}$ & $\begin{array}{c}1785.0 \\
\pm 12.1\end{array}$ & $\begin{array}{l}1795.0 \\
\pm 15.6\end{array}$ \\
\hline 8 & $\begin{array}{r}3770.0 \\
\pm 25.3 \\
\end{array}$ & $\begin{array}{c}3950.0 \\
\pm 24.2\end{array}$ & $\begin{array}{c}3970.0 \\
\pm 27.3\end{array}$ & $\begin{array}{c}4050.0 \\
\pm 25.1\end{array}$ & $\begin{array}{c}4000.0 \\
\pm 32.8\end{array}$ \\
\hline $\begin{array}{c}\text { Daily average } \\
\text { increase, g }\end{array}$ & $\begin{array}{l}70.7 \\
\pm 6.9 \\
\end{array}$ & $\begin{array}{r}77.5 \\
\pm 4.1 \\
\end{array}$ & $\begin{array}{r}77.7 \\
\pm 7.2 \\
\end{array}$ & $\begin{array}{l}80.9 \\
\pm 6.7\end{array}$ & $\begin{array}{l}78.8 \\
\pm 5.4\end{array}$ \\
\hline 12 & $\begin{array}{r}4710.0 \\
\pm 43.6 \\
\end{array}$ & $\begin{array}{c}4900.0 \\
\pm 48.6\end{array}$ & $\begin{array}{c}4990.0 \\
\pm 34.2\end{array}$ & $\begin{array}{c}5080.0 \\
\pm 44.8\end{array}$ & $\begin{array}{l}5060.0 \\
\pm 39.4\end{array}$ \\
\hline $\begin{array}{c}\text { Daily average } \\
\text { increase, } \mathrm{g}\end{array}$ & $\begin{array}{r}33.6 \\
\pm 2.4 \\
\end{array}$ & $\begin{array}{r}33.9 \\
\pm 2.1 \\
\end{array}$ & $\begin{array}{r}36.4 \\
\pm 1.2 \\
\end{array}$ & $\begin{array}{r}36.8 \\
\pm 1.8 \\
\end{array}$ & $\begin{array}{r}37.9 \\
\pm 1.8 \\
\end{array}$ \\
\hline 17 & $\begin{array}{r}5670.0 \\
\pm 98.2 \\
\end{array}$ & $\begin{array}{c}5920.0 \\
\pm 55.2 \\
\end{array}$ & $\begin{array}{c}6020.0 \\
\pm 54.1 \\
\end{array}$ & $\begin{array}{l}6250.0 \\
\pm 59.8^{*} \\
\end{array}$ & $\begin{array}{l}6160.0 \\
\pm 62.3^{*} \\
\end{array}$ \\
\hline $\begin{array}{l}\text { Daily average } \\
\text { increase, } g\end{array}$ & $\begin{array}{l}27.4 \\
\pm 2.8\end{array}$ & $\begin{array}{r}29.1 \\
\pm 3.5\end{array}$ & $\begin{array}{l}29.4 \\
\pm 2.7\end{array}$ & $\begin{array}{l}33.4 \\
\pm 5.1\end{array}$ & $\begin{array}{l}31.4 \\
\pm 4.3\end{array}$ \\
\hline $\begin{array}{c}\text { Absolute } \\
- \text {-increase, } \mathrm{g}-\end{array}$ & $\begin{array}{r}3880.0 \\
- \pm 30.2\end{array}$ & $\begin{array}{r}4140.0 \\
- \pm 32.4\end{array}$ & $\begin{array}{l}4225.0 \\
\pm 28.1\end{array}$ & $\begin{array}{l}4465.0 \\
\pm 32.6\end{array}$ & $\begin{array}{r}4365.0 \\
- \pm 29.4\end{array}$ \\
\hline $\begin{array}{c}\text { Relative } \\
\text { increase, } \\
\%\end{array}$ & 100.0 & 104.0 & 106.2 & 110.2 & 108.6 \\
\hline
\end{tabular}

Добавлено примечание ([01]): Напольный способ 
In geese receiving different doses of nanostructured zeolite, the indicators were comparable to those of birds of other groups. We assume that the use of nanostructured zeolite in feeding geese contributed to a greater manifestation of biological effects in the body in comparison with the macroscopic zeolite.

In the period from 4 to 8 weeks of age, the increase in live weight of the experimental birds was 9.6 higher than the control $(70.7 \pm 6.9 \mathrm{~g}) ; 9.9 ; 14.4$ and $11.4 \%$, respectively, of groups II, III, IV, and V.

Moreover, the average daily gain did not differ significantly in geese receiving the zeolite in the optimal dose and geese receiving the nanostructured zeolite in the dose of $1.5 \%$. The highest average daily gain in live weight $-80.9 \pm 6.7 \mathrm{~g}$ - was found in geese fed $1.0 \%$ of the nanostructured zeolite to the dry matter of the feed.

At 12 weeks of age, the highest gains in live weight were observed in geese receiving different doses of nanostructured additives. Moreover, in birds of the control group and those receiving zeolite, the average daily gain did not differ significantly.

In geese consuming nanostructured zeolite, the excess was 8.3 ; 9.5 and $12.8 \%$ (III, IV and V) in comparison with the control values $-33.6 \pm 2.4 \mathrm{~g}$. During this period, it is characteristic that the lowest dose of nanostructured zeolite is $0.5 \%$ of dry matter feed showed the best results $-37.9 \pm 1.8 \mathrm{~g}$. We assume that the administered dose of the nanostructured additive has become optimal in terms of the amount of additive components received and used in the body.

By 17 weeks of age, the average daily gain in live weight in the control geese was $27.4 \pm 2.8 \mathrm{~g}$. This indicator in the birds of the experimental groups was higher by $6.2 ; 7.3 ; 21.9$ and $14.6 \%$, in groups II, III, IV, and $\mathrm{V}$, respectively. The best results were achieved in geese receiving a nanostructured zeolite in the diet at a dose of $1.0 \%$.

An analysis of the indicators allowed us to conclude that the results were higher than the control, but did not exceed the values of the genetic growth potential of the Lindovskaya geese. In addition, the general tendency toward a decrease in the average daily gain in live weight in the dynamics of scientific and production experience corresponded to the characteristics of physiological growth and development of geese of this breed and age.

By the period of technological slaughter, the live weight of geese of the control group was $5670.0 \pm 98.2 \mathrm{~g}$. In birds of the experimental groups, these indicators were significantly higher by $4.0 ; 6.2 ; 10.2$ and $8.6 \%$ or $250.0 ; 350.0 ; 580.0$ and $490.0 \mathrm{~g} / \mathrm{animal}$.

It should be noted that the largest live weight $6250.0 \pm 59.8 \mathrm{~g}$ was achieved in geese that consumed $1.0 \%$ of nanostructured zeolite to the dry matter of the feed. The use of an excess dose of $1.5 \%$ in the diet did not contribute to a similar increase in live weight. We assume that this concentration of the nanostructured additive was excessive and caused a greater manifestation of the known sorption and abrasive effects of zeolite in the body.

The enhancement of the sorption properties of the nanostructured zeolite was established during the study of goose meat for the content of some chemical elements (Table 3).

In the meat of geese of the control and experimental groups, the content of especially dangerous chemical elements such as cadmium was less than $0.002 \mathrm{mg} / \mathrm{kg}$, lead and nickel were less than $0.02 \mathrm{mg} / \mathrm{kg}$, which indicated the meat's compliance with hygienic requirements.

Table 3. Goose meat research results.

\begin{tabular}{|c|c|c|c|c|c|c|}
\hline \multirow{2}{*}{ Indexes } & \multirow{2}{*}{\begin{tabular}{|c|} 
Allo- \\
wable \\
quantity
\end{tabular}} & \multicolumn{5}{|c|}{ Groups $(n=11)$} \\
\hline & & I & II & III & IV & V \\
\hline $\begin{array}{c}\text { Cadmiu } \\
\mathrm{m}\end{array}$ & $\begin{array}{l}\text { no more } \\
\text { than } 0.05\end{array}$ & $<0.002$ & $<0.002$ & $<0.002$ & $<0.002$ & $<0.002$ \\
\hline Lead & \begin{tabular}{|l|} 
no more \\
than 0.5 \\
\end{tabular} & $<0.02$ & $<0.02$ & $<0.02$ & $<0.02$ & $<0.02$ \\
\hline Zinc & 70.0 & \begin{tabular}{|l|}
23.6 \\
\pm 3.1 \\
\end{tabular} & $\begin{array}{l}17.0 \\
\pm 5.1 \\
\end{array}$ & $\begin{array}{c}16.2 \\
\pm 3.1 *\end{array}$ & $\begin{array}{r}16.8 \\
\pm 5.2 \\
\end{array}$ & $\begin{array}{l}17.1 \\
\pm 3.8 \\
\end{array}$ \\
\hline Copper & 5.0 & \begin{tabular}{|l|}
10.7 \\
\pm 2.2
\end{tabular} & $\begin{array}{c}9.3 \\
\pm 2.6\end{array}$ & $\begin{array}{c}5.5 \\
\pm 2.8^{*}\end{array}$ & $\begin{array}{c}6.8 \\
\pm 2.0\end{array}$ & $\begin{array}{c}7.8 \\
\pm 3.4\end{array}$ \\
\hline Nickel & $\begin{array}{l}\text { no more } \\
\text { than } 0.5\end{array}$ & $<0.02$ & $<0.02$ & $<0.02$ & $<0.02$ & $<0.02$ \\
\hline
\end{tabular}

$* \mathrm{P} \leq 0,05$

The copper content in the meat of the geese of the control group exceeded the hygienic requirements. The use of zeolite in feeding geese contributed to a decrease in copper concentration by $13.1 \%$, the use of nanostructured zeolite - by $48.6 ; 36.5$ and $27.1 \%$, respectively, of groups III, IV and V.

A similar trend was observed in the dynamics of zinc. Its content in the meat of geese that received zeolite decreased by $28.0 \%$, nanostructured zeolite - by 31.3 ; 28.8 and $27.5 \%$, respectively, of groups III, IV and V.

An analysis of the data in the table allows us to conclude that the sorption capacity of chemical elements varies significantly depending on the chemical activity of the elements, the macro- and nanostructures of the zeolite, as well as on its amount used in feeding geese. The zeolite structure, represented by conglomerates of interconnected particles, has a lower sorption capacity than individual isolated particles with active chemical bonds in the nanostructured zeolite.

In our studies, zeolite caused a decrease in zinc by 28.0 and in lead by $13.1 \%$, while nanostructured zeolite contributed to the sorption of zinc by $27.5-31.3 \%$ and copper by $27.1-48.6 \%$ depending on the dosage of use. The dose-dependent tendency of the sorption effect of nanostructured zeolite in the geese organism was noted: the use of the highest dose of the additive provided the best sorption indicators in meat.

Indicators of nutritional and energy value of meat are one of the main criteria for assessing the quality of meat and meat products.

In the meat of geese fed different amounts of nanostructured zeolite, there was an increase in mineral substances by $9.5-23.8 \%(\mathrm{P} \leq 0.05)$, in protein by $3.5-9.9 \%(\mathrm{P} \leq 0.05)$, in fat - by $2.7-6.7 \%$ and in caloric value - by $2.8-3.8 \%(\mathrm{P} \leq 0.05)$, all in comparison with controls. A decrease in the moisture content in the meat 
of experimental geese was found to be $2.9-3.7 \%$ in comparison with the control values (Table 4).

Zeolites in the feeding of geese influenced the digestive system, showing abrasive actions. The irritation caused by the additive on the intestinal suction apparatus contributed to the enhancement of parietal digestion and increase in feed conversion. In addition, zeolites helped to slow the passage of fodder masses through the organs of the gastrointestinal tract, which also increased feed conversion.

The macro- and microelements of natural origin included in the additive had a positive effect on the mineral metabolism in the body of young geese, which was significant during the growth of the skeleton of birds with the formation of a feather.

All these factors contributed to improving the quality of goose meat with an increase in its content of protein, fat, mineral components and a decrease in moisture.

Table 4. The chemical composition and calorie content of goose meat

\begin{tabular}{|c|c|c|c|c|c|}
\hline \multirow{2}{*}{ Indicators } & \multicolumn{5}{|c|}{ Groups (n=11) } \\
\cline { 2 - 6 } & I & II & III & IV & V \\
\hline protein, \% & $17.2 \pm 0.6$ & $17.5 \pm 0.5$ & $17.8 \pm 0.4$ & $18.9 \pm 0.7 *$ & $18.3 \pm 0.5 *$ \\
\hline fat, \% & $7.4 \pm 0.3$ & $7.6 \pm 0.6$ & $7.6 \pm 0.5$ & $7.9 \pm 0.4$ & $7.8 \pm 0.5$ \\
\hline $\begin{array}{c}\text { minerals, } \\
\%\end{array}$ & $2.1 \pm 0.2$ & $2.4 \pm 0.1$ & $2.4 \pm 0.1$ & $2.6 \pm 0.2 *$ & $2.5 \pm 0.3$ \\
\hline $\begin{array}{c}\text { moistur, } \\
\%\end{array}$ & $75.6 \pm 1.2$ & $73.4 \pm 1.1$ & $72.8 \pm 0.9 *$ & $73.0 \pm 1.4$ & $73.4 \pm 1.2$ \\
\hline $\begin{array}{c}\text { calorie } \\
\text { meat 100 } \\
\text { g, kJ }\end{array}$ & $422.0 \pm 7.1$ & $431.5 \pm 5.6$ & $434.0 \pm 6.4$ & $438.0 \pm 6.1 *$ & $435.0 \pm 7.4$ \\
\hline$* \mathrm{P} \leq 0,05$ & & & & \\
\hline
\end{tabular}

\section{Conclusion}

The use of different doses of the feed additive of nanostructured zeolite during the growing and fattening of geese led to an increase in their average daily gain in live weight by $6.2-10.2 \%$.

The greatest increase in meat productivity was achieved with the use of nanostructured additives in a dose of $1.0 \%$ to the dry matter of the feed. The nanostructured zeolite contributed to a decrease in the meat content of geese of the zinc content by $27.5-31.3 \%$ and copper - by $27.1-48.6 \%$ in comparison with the control.

The high sorption properties of nanostructured zeolite and its dose-dependent biological and sorption effects in the body of geese have been established.

\section{Acknowledgements}

The authors are grateful to the Cand. Chem. Sciences V.E. Katnov for certification of the studied zeolites.

\section{References}

1. E. Nazife, E. Mevlut, A. Christos, Sci. of Food and Agricul. 97, 3487-3499 (2017)

2. O. Nazarenko, R. Zarubina, A. Weissheim, News of Tomsk Polytech. Univer. 319, 38-32 (2011)

3. V. Ezhkov, A. Yapparov, E. Nefediev, A. Ezhkova, I. Yapparov, A. Gerasimov, Bull. of Kazan Technol. Univer. 17, 41-45 (2014)

4. E. Semenov, S. Tanaseva, A. Valiev, E. Gubeeva, R. Biktashev, Veterinarian. 3, 30-34 (2017)

5. K. Papunidi, R. Biktashev, S. Bulankova, Veter. J. 3, 8-12 (2014)

6. T. Prasai, K. Walsh, S. Bhattarai, D. Midmore, T. Van, R. Moore, D. Stanley, Microb. Res. J. 24 24-30 (2017)

7. S. Dezhatkina, A. Muhitov, A. Dozorov, Pig. Prod. J. 7, 26-28 (2012)

8. A. Ezhkova, R. Fayzrakhmanov, Sh. Shakirov, R. Faizrakhmanov Jr., Bull. of Kazan Technol. Univer. 17, 149-151 (2014)

9. A. Aidash, Exp. Studies 1, 115-122 (2016)

10. S. Wang, V. Peng, Chemic. Engender. 156, 11-24 (2010)

11. I. Yapparov, V. Ezhkov, V. Katnov, A. Yapparov, L. Bikkinina, G. Ezhkova, P. Grishin, A. Ezhkova, Dokl. Chem. J. 481, 173-176 (2018)

12. M. Gamidov, T. Truhina, Veter. J. 2, 57-59 (2015)

13. N. Toprak, A. Yılmaz, E. Öztürk, O. Yigit, F. Cedden, South African J. of Animal Sci. 46, 313320 (2016)

14. L. Bacakova, M. Vandrovcova, I. Kopova, I. Jirka, Biomat. Sci. J. 6, 974-989 (2018)

15. N. Hossein, S. Khorram, H. Rezazadeh, A. Safaiyan, A. Tarighat-Esfanjani, Can. J. of Diabetes 42, 31-35, 42(1), 31-35 (2018)

16. R. Demirel, M. Baran, D. Demirel, K. Aydın, Y. Beran, Tarim. Bil. Dergisi. J. 24, 297-302 (2018)

17. S. Pavelic, V. Micek, A. Filošević, D. Gumbarević, P. Žurga, A. Bulog, T. Orct, Y. Yamamoto, T. Preočanin, J. Plavec, R. Peter, M. Petravić, Mic. and Mes. Mater. J. 249, 146-148 (2017)

18. H. Valpotić, D. Gračner, R. Turk, D. Đuričić, S. Vince, I. Folnožić, M. Lojkić et al., Per. Biolog. J. 119, 159-172 (2017)

19. A. Yapparov, L. Kovalenko, Scientific substantiation of obtaining nanostructured and nanocomposite materials and the technology of their use in agriculture (Center for Innov. Technol., 2014), $304 \mathrm{p}$.

20. S. Nakhon, S. Numthuam, R. Charoensook, W Tartrakoon, P. Incharoen, T. Incharoen, Animal Nutrition J. 5, 152-155 (2019) 